\title{
In Memory of Geoffrey Leech
}

Prof. Geoffrey Leech, an influential scholar who left an indelible mark across many linguistic disciplines and inspired a generation of linguists, died suddenly on 19 August 2014.

Geoff was born in Gloucester in 1936, and after his National Service in the Royal Air Force he studied English Language and Literature at University College, London, graduating in 1959. During this time he attended lectures by J.R. Firth, the first professor of linguistics in the UK. In 1966 Geoff published his first book: English in Advertising: A Linguistic Study of Advertising in Great Britain. He also made significant contributions to the field of stylistics (A Linguistic Guide to English Poetry, 1969), as well as to semantics and pragmatics (Principles of Pragmatics, 1983) with his last book Pragmatics of Politeness being published by Oxford University Press only a few months ago.

Geoff was considered one of the founders of the field of corpus linguistics. He was a member of the groups that compiled and annotated the Lancaster-Oslo-Bergen Corpus (LOB) and the British National Corpus (BNC). In recent years he carried out significant work on the computational analysis of English, using computer corpora.

He was not only an eminent scholar however, but also a modest, approachable and supportive individual. In recognition of his outstanding contributions to linguistics, I proposed that he be awarded the title Honorary Doctor of Letters at my own university in 2002. I have had the privilege of knowing Geoff personally, and cherished all the opportunities I had to work with him. It was only last year that Geoff, one of my PhD students, and myself produced a joint publication on using Natural Language Processing techniques to track Diachronic Changes in TwentiethCentury English Language.

The linguistics, corpus linguistics and computational linguistics communities have lost an eminent scholar, and a kind and supportive colleague and friend. 